\title{
The Barriers of Teaching Speaking English for EFL Learners
}

\author{
Kristi Nuraini \\ University of Muhammadiyah Jember \\ (kristinuraini@yahoo.com)
}

\begin{abstract}
This research portraits the barriers in teaching speaking for EFL learner. The barriers in teaching speaking English come form two aspects: internal and external factors. Internal factors are native language, age, exposure, innate phonetic ability, identity and language ego, and motivation concern for good speaking English and external factors are teaching speaking English at large class and learners' autonomy. Each barrier is connected with the available method used in teaching speaking English. The conclusion of this research is teacher must focus on the learners need, the second is teacher applies for environment analysis before conducting teaching speaking English, the last is teacher chooses the suitable method based on the problems that he/she found in his/her teaching speaking English. Several methods that are often used in teaching speaking English are Direct Method, The Silent Way, Community Language Learning, Total Physical Response, and Communicative Language Teaching.
\end{abstract}

Keywords: barriers in teaching speaking, internal factors, external factors

Speaking is one of four skills in language skill. Speaking and writing are productive skill, Listening and reading are receptive skill. All skills are importance in terms of communication, including English Communication face Global English. The importance in terms if communication is how to develop speaking English for EFL Learners (Especially for learners who are staying in Indonesia).

Four skills in language skill are importance, but the most importance is speaking skill. By using speaking skill, the learners are able to communicate to others by using English to face Asean Free Trade Area (AFTA) and Global English. According some theories, speaking is an interactive process of constructing meaning that involves producing and receiving and processing information (Brown, 1994; Burns \& Joyce, 1997). Speaking is "the process of building and sharing meaning through the use of verbal and non-verbal symbols, in a variety of contexts" (Chaney, 1998 , p. 13). Hornby (1995, p. 37) says that teaching means giving the instruction to (a person): give a person (knowledge skill, etc.). While speaking means to make use of words in an ordinary voice. So, teaching speaking is giving instruction to a person in order to communicate. From the definition, it can be defined that speaking is expression in delivering or sending message from 1st speaker to the $2^{\text {nd }}$ speaker (interlocutors). As we know, in delivering or sending message in speaking uses verbal language and the accuracy and understanding of both speakers will decide the success of communication.

There are some methods to support teaching speaking English for EFL learners are 
Direct Method, The Silent Way, Community Language Learning, Total Physical Response, and Communicative Language Teaching.

Direct Method receives its name from the fact that meaning is conveyed directly in the target language through use of demonstration and visual aids, with no recourse to the learners' native language (Diller, 1978). The Silent Way supposed that learning is a process which we initiate by ourselves by mobilizing our inner resources to meet the challenge at hand. Community Language Learning, by applying this method, learners' confident will appear and they will be communicative in saying something based on their idea because teachers support them and consider their learners as "whole persons". Total Physical Response, in this method after the learner internalizes an extensive map how the target language works, speaking will appear spontaneously. Communicative Language Teaching became clear that communication required that learners perform certain functions as well, such as promising, inviting, and declining invitations within a social context (Wilkins, 1976).

Although there are many approaches in teaching speaking, the learning process still faces many failures. There are many problems which influence the failure that are Clustering, Redundancy, Reduced forms, Performance variables, Colloquial language, Rate of delivery, Stress rhythm and Intonation, Interaction.

All of the barriers have to be observed in order to reach the success of teaching speaking. The observation result will help teachers in deciding the available method in teaching speaking. The result also can be a source in developing approaches or methods in EFL. Teaching speaking needs to know about barriers that may be occur in the learning process.

Brown in Islamiyah (2007, p. 14) states that speaking is a productive skill that can be directly and empirically observed, those observations are invariably collared by the accuracy and fluency. While, he also states that speaking is the product of creative construction of linguistic strings, the speakers make choices of lexicon, structure, and discourse. It means that speaking used in terms of communication. Speaking is the most important skill among four skills (listening, speaking, reading, and writing) because people who know a language are referred to as speakers of that language. This indicates that using a language is more important than just knowing about it because "there is no point knowing a lot about language if you can't use it" (Scrivener, 2005, p. 146).

The focus of teaching speaking, of course, is to improve the oral production of the students. Therefore, language teaching activities in the classroom should aim at maximizing individual language use (Haozhang, 1997). In the past, oral communication instruction was neglected because of the misconception that oral communication competence develops naturally over time and that the cognitive skills involved in writing automatically transfer to analogous oral communication skills (Chaney, 1998).

Talking about speaking, it relates with language acquisition, oral language acquisition. Oral language acquisition is a natural process for children. It occurs almost without effort. The ability to speak grows with age, but it does not mean that such growth will automatically lead to perfection. To speak in more effective ways requires particular attention and constant practice (Zhang et al., 1995). Speaking fluency appears to develop with increased exposure to second language(L2) input (Al-Sibai, 2004). Input refers to the language data which the learner is exposed (Zhang, 2009).

Although it is widely recognized that input is very essential for language acquisition, it will not be sufficient if it is not followed by interaction and output (the language a learner produces) because the processing of comprehension is different from the processing of production, and the ability to understand the meaning conveyed by sentences differs from the ability to use a linguistic system to express meaning. (Swain, 1985, as cited in Zhang, 2009). When input is negotiated and learners produce output in interaction, they selectively "take in" portions of comprehensible 
input and choose a correct linguistic form to express themselves. This process makes it possible for the learners to internalize what they have learned and experienced.

Oral language acquisition always related to speaking English. Other factor which promotes students when learning to master the speaking English is when they have had enough English oral exposure when they were still a child. If they did not get enough oral exposure of English, they will find it difficult to speak up when they are adults. This is due to the influence of oral language acquisition which interfere the ability to pronounce the language correctly. On other words, the more the exposure one has had will help him to have a better understanding and better ability in oral language to promote their ability in speaking the language.

When language learning takes place, there are four conditions that should be exist, and they are the exposure, opportunities to use the language, motivation, and instruction. Learners need chances to say what they think or feel and to experiment in a supportive atmosphere using language they have heard or seen without feeling threatened (Willis,1996, p. 7). A fact that is highlighted by second language research is that progress does not occur when people make a conscious effort to learn. Progress occurs as a result of spontaneous, subconscious mechanisms, which are activated when learners are involved in communication with the second language. The subconscious element demands a new range of activities, where learners are focused not on the language itself but on the communication of meaning (Littlewood, 1984). Harmer (1982) also argued that in a communicative task, the students' attention should be focused on the content of what they are saying, rather than the form. They should use a wide variety of language.

Rod Ellis (2009, p. 775) stated that oral language learning can be done by involving learners in performing two types of communicative tasks: focused communicative tasks and unfocused communicative tasks. Both of these tasks seek to engage learners in using language pragmatically rather than displaying language. They seek to develop language proficiency through communication. "Through communication, learners can integrate separate structures into a creative system for expressing meaning" (Littlewood, 1984, p. 91).

Oral language learning is the contrary of the oral language acquisition. If the oral language acquisition is the human being addition in oral communication when they were still a child. Otherwise oral language learning must be learned by the human being in an institution. Oral language learning support students ability in speaking skill. Oral language learning can be studied inside and outside the class. Oral language learning can improve student's ability in speaking skill through interaction. Because when we speak, we need the second speaker or receiver, this situation makes the interaction happened. Through interaction, oral language learning can be maximum enhancing student's capability in speaking English.

\section{Method}

In this research, the researcher used qualitative research design. Fraenkel and Wallen (2006) define qualitative research as documenting or portraying the everyday experience of individuals by observing and interviewing them. In this case, the data is from observation and documents. For collecting the related data, the writer uses in depth interviewing and content analysis. While checking the data validity, this study applies source and method triangulations. The model of interactive analysis is used to analyze the collect data.

\section{Result and Discussion}

Some barriers come from the internal and external factors when teaching speaking English for EFL learners. Those aspects will be discussed as follows; 


\section{Internal factors}

Internal factors of teaching speaking English for EFL learners are commonly become obstacles in teaching speaking English. The problems are native language, age, exposure, innate phonetic ability, identity and language ego, motivation and concern for good speaking.

\section{Native language}

The native language is the most influential factor affecting a learner's speaking. Brown, (2000, p. 284) states, "If you are familiar with the sound system of learner's nativelanguage, you will be better able to diagnose learner difficulties. Many L1-L2 carry overs can be overcome through a focused awareness and effort on the learner's part."

By the statement it concludes that mother language of learners will be a problem in teaching speaking English, if the teacher cannot understand the fact and decided a way to solve the condition moreover if the linguistic aspect of the native languagelearners have is English as Foreign Language (EFL) and it is totally different with target language. In the condition, linguistically, the difference of L1 and L2 is the fundamental factor that determines success of a speaking class.

\section{Age}

Children who are speaking English under the age of puberty stand an excellent chance of "sounding like a native" if they have continued exposure in authentic contexts. Beyond the age of puberty, while adults will almost surely maintain a "foreign accent", there is no particular advantage attributed to age. A fifty year old can be as successful as an eighteen year old if all other factors are equal. Although, Brown, (2000, p. 284) argues that remind the learners are older, that "the younger, the better" is a myth. It is because, in fact, every step of age has its own characteristic that sometimes has a potency to be a problem in teaching speaking.

Learners are often described as children, young learners, adolescents, young adults or adults, (Harmer, 2007, p. 14). The term children are generally used for learners between the ages of about 2 to about 14 . Learners are generally described as young learners between the ages of 5 to 9 and very young learner are usually between 2 and 5 . Adult are generally thought to be between 16 and 20 .

Brown, (2000, p. 87) gives clearer map of children characteristic that could be problem in language teaching. Children are still in an intellectual stage. Therefore, theyare centered on the here and now, on functional purposes of language. They have little appreciation for our adult notions of "concreteness" and they certainty cannot grasp the metalanguage used to describe and explain linguistics concepts.

Actually children are often innovative in language forms but still have a great many inhibitions. They are extremely sensitive, especially to peers. Moreover, their egoism is still being shaped, and therefore the slights of communication can be negatively interpreted. Children are also focused on what this new language can actually be used for here and now. They are less to willing to put up with language that doesn't hold immediate that is neither authentic nor meaningful.

Adults have a wider range of life experiences to draw on, both as individual and as learners than younger learners do. Adult comes with a lot of previous learning experiences which may hamper their progress, (Harmer, 2007, p. 15). Brown, (2000, p. 90) also says that adults usually have acquired a self-confidence not found in children. Unfortunately, adults have weakness that often brings a modicum of general self-confidence(global self-esteem)intodassroom.

From the aforementioned explanation, it can be concluded that teaching language is really related with the age of learners that affect the characteristic of the learners its self. In every age there is some uniqueness which can support the teaching processes on other hand the uniqueness can be hard obstacle in the teaching. It can be anticipated by making an observation about the age of learners and find the formula in teaching each age.

\section{Exposure}

It is difficult to define exposure. One can actually live in a foreign country for sometime but not take advantage of being "with the people." Research seems to support the notion that the quality and intensity of exposure are more important than mere length of time. Brown, (2000, p. 285) says that 
if class time spent focusing on speaking demands the full attention and interest of the learners, then they stand a good chance of reaching their goals.

The statement shows that in terms of exposure the discussion will be very fuzzy. Some learners may be more interest by quality and intensity of exposure the teacher gives in speaking class. Some of the learners may have contradictive condition; they prefer to get long time of exposure in reaching the speaking class goal. The relativity is an obstacle in teaching speaking so the teacher should know the condition of his or her learners in order to be able to give suitable exposure.

\section{Innate phonetic ability}

Often referred to as having an "ear" for language, some people manifests a phonetic coding ability that others do not. In many cases, if a person has had exposure to a foreign language as a child, this "knack" is present whether the early language is remembered or not, (Brown, 2000, p. 285). Others are simply more attuned to phonetic discriminations. Some people would have you believe that you either have such a knack, or you do not. Therefore, if speaking seems to be naturally difficult for some learners, they should not despair; with some effort and concentration, they can improve their competence.

In other words, sometime speaking skill often placed as a talent from an individual. The perspective is not wrong because many researches, especially in education have proven that human has specific talent or inelegance. Here, speaking skill mastery includes verbal intelligence. So, the teacher should understand the fact by realizing that learners have their own chance to be success in speaking class. It will a big problem if the teacher do not see his learners in diverse talent.

\section{Identity and language ego}

Yet another influence is one's attitude toward speakers of the target language and the extent to which the language ego identifies with those speakers. Learners need to be reminded of the importance of positive attitudes toward the people who speak the language, but more important, learners need to become aware of - and not afraid of - the second identity that may be emerging within them, (Brown, 2000, p. 285).

The perspective shows that learners' attitude is very important in speaking class. Positive attitude will help the learners to master speaking skill better. On the contrary, by bad attitude, the learners will be more difficult to reach the speaking class goal. Good attitude is a power that helps the learners to accept speaking material. It will be a huge trouble if the teacher does not know the importance of Identity and language ego of his learners.

\section{Motivation and concern for good speaking}

Some learners are not particularly concerned about their speaking, while others are. The extent to which learners' intrinsic motivation propels them toward improvement will be perhaps the strongest influence of all six of the factors in this list. Brown, (2000, p. 285) says that motivation and concern are high, and then the necessary effort will be expended in pursuit of goals. It means that motivation is very important in teaching speaking.

The teacher does not have other choice except to try to wake learners' motivation. The problem is that motivation is a very complex thing. Motivation means a cluster of factor that 'energizes' the behavior and gives it 'direction' (Atkinson, 2000, p. 13). In Atkinson point a view, motivation is term used to describe what energize a person and what directs his activity, and energy and direction are the center of motivation. Furthermore, Motivation is divided into intrinsic and extrinsic motivation (Arnold, 2000,p. 14). The problem here is that how to build both intrinsic and extrinsic motivation from the learners. Moreover, each learner has his own characteristic so it needs many strategies and approach to make up the motivation.

Learning to speak English in Foreign Language (EFL) will be facilitated when learners are actively engaged in attempting to communicate (Richard, 1995, p. 51). In terms of motivating learners communication, teacher can help learners to perceive or develop their motivation by showing, among other things, how clarity of speech is significant in shaping their self image and ultimately in reaching some of their higher goals in Speaking English. 


\section{External factors}

The effectiveness of teaching speaking does not only come from internal aspects of the learners but also influenced by external factors. The completeness understanding of problem in teaching speaking should be known by the teacher. The factor is an institutional context that puts English as foreign language in a nation. The context in which the language is learnt is still considerable relevance to kind of English a nation will want and need to study, and the skills they will need to acquire.

Harmer, (2007, p. 12) says there are three main kinds of English teaching. It has been suggested that learners of EFL (English as Foreign Language) tend to be learning so that they can use English when traveling or to communicate with other people, from whatever country, who also speak English. ESL (English as a Second Language) learners, on the other hand, are usually living in the largest-language community. The latter may need to learn the particular language variety of that community (Scotch English, shouter English, from England, Australian English, and Texan English). ESOL (English for Speakers of Other Languages) to describe both situations.

\section{Teaching Speaking English at Large Class}

Teaching learners at large class is always debatable, especially for countries that use English as Foreign Language (EFL). Marcus (1997) in his article "Large Class Size: Strategies for Success" poses the question "how large is large?" regarding the class size. He also presented the ratio of language students in different countries which explicitly shows that the concept of large class varies from country to country. Marcus, for instance, shows that in USA the average large class size is 80 , in India its 45 , whereas in Hong Kong it is 16 and in Singapore it is 20.

Some problems faced at large class are space problem for both teacher and students; physical discomfort; Intimidating atmosphere; Students tend to miss classes to avoid participation in activities; giving individual attention becomes difficult for the teacher; Teacher's feedback is not proper enough and the teacher feels guilty; In the mixedabilityclassesitisdifficult to solveall the problems.
In order to convert the difficulties in having large class, the teacher need to be focused on learners' need. Teacher needs to have an open mind to be innovative to help the learners to attain success regarding speaking. More and more modern approaches and methods should be introduced. Ultimately theexperiences gathered from theseclasses become an invaluable asset for a language teacher.

\section{Learners' Autonomy}

In teaching speaking English as Foreign Language the learners must be ready to the target language both outside and inside language classroom. The learners have a tremendous advantage. They have an instant "laboratory" available twenty-four hours a day. Because of that, it is easier to teach English as second language than as foreign language.

Language teaching in what might broadly categorize as an EFL context is clearly a greater challenge for learners and teachers. Often, intrinsic motivation is a big issue, since learners may have difficulty in seeing the relevance of learning English, (Brown, 2001, p. 118). Their immediate use of language may seen far from removed from their own circumstances, and classroom hours may be the only part of the day when theyare exposed to English.

Moreover, speaking is a skill that very needs many exercises. In EFL, the time to do exercise is limited in the classroom. When the learners out from the class they will use their mother language. From the fact, the teacher should choose the most suitable method in teaching speaking. Therefore, the language that teacher present, model, elicit, and treat takes on great importance.

\section{Conclusion}

Teaching speaking is a very important part of foreign language learning. The ability to communicate in a foreign language clearly and efficiently contributes to the success of the learner in school and success later in every phase of life. Therefore, it is essential that language teachers pay great attention to teaching speaking. Rather than leading learners to pure memorization, providing 
a rich environment where meaningful communication takes place is desired. With this aim, various speaking activities such as those listed above can contribute a great deal to learners in developing basic interactive skills necessary for life.

Problem in teaching speaking is complex. It is not only related with the learners' factor but also about context outside. In the internal aspects, the problems occurred are related with native language, age, exposure, innate phonetic ability, identity and language ego, and motivation and concern for good speaking. The points of those problems are related with condition of the learners. In the external problems are teaching speaking at large class and learners' autonomy.

Based on the problems above, it suggests to the teacher: the first is teacher must focus on the learners need, the second is teacher applies for environment analysis before conducting teaching speaking English, the last is teacher chooses the suitable method based on the problems that they found in his/her teaching speaking English. Several methods that are often used in teaching speaking Englis are Direct Method, The Silent Way, Community Language Learning, Total Physical Response, and Communicative Language Teaching. Hopefully, by these activities, learners more active in the learning process and at the same time make their learning more meaningful and fun for them.

\section{References}

Al-Sibai, D. (2004). Promoting oral Fluency of Second Language Learners: Educational Linguistics Department of English. King Saud University, see Adult Learners of English.

Brown, Douglas. (2001). Teaching by Principle. Pearson Education, Inc.

Brown, H.D. (1994). Teaching by principles: an interactive approach to language pedagogy. Englewood Cliffs, NJ: Prentice Hall Regents
Chaney, A.L., and T.L. Burk. (1998). Teaching Oral Communication in Grades K-8. Boston: Allyn \& Bacon.

Diller, K. C. (1971). Generative Grammar, Structural Linguistics and Language Teaching. Rowley, Mass.: Newbury House.

Fraenkel, J.R. , \& Wallen, N.E. (2006). How to design and evaluate research in education, New York: McGraw - Hill.

Harmer, Jeremy. (2007). How to Teach English. Edinburg. Longman.

Hornby, A.S.(2002). Oxford Advanced Learners Dictionary of Current English. Britain: Oxford University Press.

Islamiyah, Suaibatul. (2007). Teaching Speaking Through VCD for Second Year Students of SMPN 1 Labuan Haji in the School Year 2006/2007.

Marcus, S (1997). Large Class Size: Strategies for Success the English Teacher, 26. Retrieved from http://www.melta.org. my/ET/1997/main6.html

Richard, Jack C.(1995). The Language Teaching Matrix. Cambridge Language Teaching Library, City Polytechnic of Hongkong 
